\title{
HYDROPHILIC POLYMER CHANGES THE WATER DEMAND IN THE IMPLEMENTATION OF A DWARF CASHEW ORCHARD
}

\author{
Rubens S. Gondim ${ }^{1 *}$, Luiz A. L. Serrano ${ }^{1}$, Aline de H. N. Maia ${ }^{2}$, Janderson P. da Silva ${ }^{3}$ \\ ${ }^{1 *}$ Corresponding author. Embrapa Agroindústria Tropical/ Fortaleza - CE, Brasil. \\ E-mail: rubens.gondim@embrapa.br | ORCID ID: https://orcid.org/0000-0001-7887-1832
}

\section{KEYWORDS}

Anacardium occidentale L., climate change, adaptation, soil amendment, biochar.

\begin{abstract}
Important losses of dwarf cashew seedlings during the establishment of orchards in the Brazilian semiarid are related to the relatively short rainy season. This study aimed to evaluate biochar and hydrophilic polymer as soil amendments to increase water retention and reduce plant death in the first year. An experiment was conducted at the Curu Station, Paraipaba, CE, Brazil, using the clone BRS 226. The experimental design consisted of randomized blocks, with amounts of $0.5,1.0,2.0$, and $4.0 \mathrm{~kg}$ of cashew wood biochar and $20,40,60,80 \mathrm{~g}$ of hydrophilic polymer applied per pit, as well as a control treatment (no soil amendment). Seedlings were submitted to an irrigation regime to avoid water stress (5 $\mathrm{L}$ water seedling ${ }^{-1}$ when the tensiometer installed at a depth of $0.15 \mathrm{~m}$ reached $60 \mathrm{kPa}$ ). The variables of plant development number of leaves, plant height, stem diameter, and canopy diameter were evaluated up to 374 days after transplanting to the field. The analysis of variance showed no treatment effect on plant development. However, minimum water consumption was observed when $29.56 \mathrm{~g}$ of hydrophilic polymer was applied per pit, providing $100.0 \%$ seedling survival.
\end{abstract}

\section{INTRODUCTION}

The introduction of dwarf cashew was essential to reduce the deforestation, with contributions to the environment and restructuring of the Caatinga biome domain (Alencar et al., 2018). Cashew is a native species to the Northeast region of Brazil considered tolerant to water stress, but seedling losses that reach up to $50 \%$ can be observed when planting orchards in years of irregular precipitation. Despite being a drought-tolerant species, water is considered one of the main limiting factors for the cashew crop (Carr, 2014). Soil and water conservation techniques in areas with limited irrigation structure may increase cashew yield and, consequently, producer income.

The cashew crop is commonly developed on Quartzipsamment soils, which have low cation exchange capacity and water retention (Xavier et al., 2013). Measures for soil and water conservation in cashew fields, such as the use of buried coconut shell, increase crop yield (Rejani \& Yadukumar, 2010) due to increased soil moisture retention. According to Sajeev et al. (2014), the use of soil and water conservation technologies has a high correlation with cashew production in India.

Biochar is the product from the incomplete combustion of organic materials, and its addition to agricultural soils has been proposed to increase the water retention capacity, mitigate the effects of climate change by increasing soil carbon sequestration and reducing greenhouse gas emissions and improve soil fertility (Karhu et al., 2011). Elshaikh et al. (2017) reported positive effects of biochar on the tolerance of okra plants to soil salinity, while Pimenta et al. (2019) reported that the use of biochar from cashew wood resulted in an increased $\mathrm{pH}$ and potassium, phosphorus, and sodium contents. Kammann et al. (2011) reported an increase in soil-water retention capacity when using biochar, giving plants a high tolerance to drought.

In addition, Novotny et al. (2015) reported increased water retention for most of the different types of tested biochars. Omondi et al. (2016) pointed out an increase in available water as the most relevant effects of adding biochar to soils. Likewise, Lim et al. (2016) indicated the effect of reducing hydraulic conductivity in coarse-textured soils, Moragues-Saitua et al. (2017), Batista et al. (2018), and Villagra-Mendoza \& Horn (2018) reported the effect of biochar porosity on soil water retention, while Gonzaga et al. (2019) reported an increase in water use efficiency.

\footnotetext{
${ }^{1}$ Embrapa Agroindústria Tropical/ Fortaleza - CE, Brasil.

${ }^{2}$ Embrapa Meio Ambiente/ Jaguariúna - SP, Brasil.

${ }^{3}$ Universidade Federal do Ceará/ Fortaleza - CE, Brasil. 
One of the strategies reported to increase water use efficiency is the deficit irrigation in dense planting systems (Mangalassery et al., 2019), but Güereña et al. (2019) reported that the positive effects of biochar are conditioned to the absence of water stress. Mao et al. (2019) reported that biochar addition increased water retention capacity in hydrophobic soils with low total organic carbon content. Verheijen et al. (2019) confirmed an increase in water retention for sandy and sandy loam soils. Danso et al. (2019) reported increased water productivity in corn grown under the application of biochar made from rice husk. Therefore, the use of biochar to improve soil physical-hydraulic characteristics has become an alternative for fruit crop producers.

The hydrophilic polymer is another soil amendment that has been used to retain water in the soil. Sarvas et al. (2007) reported that hydrophilic polymer application in the preparation of pine seedlings caused an improvement in the survival rate by $19 \%$, with the best performance when it was applied in the pit. Marques et al. (2013) reported that the use of hydrophilic polymer at a dose of $2 \mathrm{~g}$ per polyethylene bag as a substitute for irrigation provided coffee seedlings of the same quality as those irrigated. Noumura et al. (2019) applied this polymer to papaya seedlings and observed better development. Also, Kraisig et al. (2018) obtained maximum yield when testing this product in the corn/oat system.

Periodic supply of cashew firewood can be found in the producing regions, which is related to the pruning required by the crop. This material could be used by producers due to the potential benefits reported in the literature. Thus, this study aimed to evaluate the application of cashew wood biochar and hydrophilic polymer as water retention agents and the increase of plant survival in the implementation of cashew orchards.

\section{MATERIAL AND METHODS}

This study was carried out from January 2016 to January 2017 at the Curu experimental field, belonging to Embrapa Tropical Agroindustry, located in the municipality of Paraipaba, CE, Brazil. The regional climate is Aw (tropical with a dry winter), according to Köppen classification, and C1 (dry subhumid), according to Thornthwaite classification (Muniz et al., 2017). The annual precipitation is around $1,000 \mathrm{~mm}$, and the rainy season is concentrated from February to May.

The result of the soil analysis in the experimental area showed a medium to sandy texture at the $0-30 \mathrm{~cm}$ layer (805 $\mathrm{g} \mathrm{kg}^{-1}$ of sand, $76 \mathrm{~g} \mathrm{~kg}^{-1}$ of clay, and $119 \mathrm{~g} \mathrm{~kg}^{-1}$ of silt) and a medium texture at the other layers, with characteristics of a Ultisol (Embrapa, 2013). The maximum organic matter content was $6.4 \mathrm{~g} \mathrm{dm}^{-3}, \mathrm{pH}$ varied from 5.6 to 6.3 between the layers, cation exchange capacity from 31.3 to 64.8 , and maximum sum of bases of $62 \%$ at the most superficial soil layer.

Seedlings of the clone BRS 226 of dwarf cashew with 120 days of age from sowing or 60 days after grafting were prepared at the Pacajus Experimental Station belonging to Embrapa Tropical Agroindustry. Pits with a circumference of $0.40 \mathrm{~m}$ and depth of $0.40 \mathrm{~m}$ were drilled using a drill attached to the Massey Ferguson 275 tractor. These pits were fertilized with $80 \mathrm{~g} \mathrm{pit}^{-1}$ of dolomitic limestone, $400 \mathrm{~g} \mathrm{pit}^{-1}$ of single superphosphate, $50 \mathrm{~g} \mathrm{pit}^{-1}$ of potassium chloride, and $50 \mathrm{~g} \mathrm{pit}^{-1}$ of FTE BR 12. Also, the seedlings received $130 \mathrm{~g} \mathrm{pit}^{-1}$ of urea and $100 \mathrm{~g} \mathrm{pit}^{-1}$ of potassium chloride split into two monthly applications from 45 days after planting. A total of 216 cashew seedlings of the clone BRS 226 were planted with a spacing of $8 \mathrm{~m}$ between rows and $4 \mathrm{~m}$ between plants, totaling 12 rows with 20 plants per row of $50 \mathrm{~m}$.

The orchard was implemented under a randomized block design, with nine treatments and four replications with six plants per plot. The treatments $\mathrm{T} 1, \mathrm{~T} 2, \mathrm{~T} 3$, and $\mathrm{T} 4$ corresponded to the application of cashew wood biochar at planting time, with amounts of $0.5,1.0,2.0$, and $4.0 \mathrm{~kg}$ per pit, respectively. The treatments $\mathrm{T} 5, \mathrm{~T} 6, \mathrm{~T} 7$, and $\mathrm{T} 8$ corresponded to the application of the Hydroplan ${ }^{\circledR}$ hydrophilic polymer, also during planting time, at doses of 20, 40, 60, and $80 \mathrm{~g}$ per pit, respectively. Moreover, the treatment T9 corresponded to the control without the application of biochar or hydrophilic polymer.

The result of the chemical analysis of the cashew wood biochar is shown in Table 1. Water retention capacity, determined in a Hainnes funnel at the field capacity $(10 \mathrm{kPa})$, was 0.53 and $0.57 \mathrm{~g} \mathrm{~g}^{-1}$ for particle size diameters of 4 and $2 \mathrm{~mm}$, respectively (Gondim et al., 2018). Both the biochar and the polymer were applied dry and at the pit.

TABLE 1. Chemical analysis of the cashew wood biochar.

\begin{tabular}{ccccccccccccc}
\hline \multicolumn{4}{c}{ Macronutrient $\left(\mathrm{g} \mathrm{kg}^{-1}\right)$} & \multicolumn{1}{c}{ Micronutrients $\left(\mathrm{mg} \mathrm{kg}^{-1}\right)$} & $(\%)$ & \multicolumn{2}{c}{$\mathrm{dS} / \mathrm{m}$} \\
\hline $\mathrm{N}$ & $\mathrm{P}$ & $\mathrm{Mg}$ & $\mathrm{Na}$ & $\mathrm{S}$ & $\mathrm{K}$ & $\mathrm{Cu}$ & $\mathrm{Fe}$ & $\mathrm{Zn}$ & $\mathrm{Mn}$ & $\mathrm{C}_{\text {total }}$ & $\mathrm{pH}$ & $\mathrm{EC}$ \\
3.5 & 1.2 & 4.0 & 1.4 & 1.6 & 7.3 & 2.0 & 363 & 16 & 42 & 62.5 & 7.26 & 0.32 \\
\hline
\end{tabular}

After planting, cashew seedlings were subjected to a rescue irrigation regime, in which water was applied with a tank coupled to a tractor. An amount of water of $5 \mathrm{~L}_{\text {plant }}{ }^{-1}$ was estimated each time the tensiometer installed at $0.15 \mathrm{~m}$ depth reached $60 \mathrm{kPa}$ to avoid water stress, considering an ETo of $49 \mathrm{~mm} \mathrm{week}^{-1}$, Kc of 0.48 , efficiency of $50 \%$, and plants occupying an area of $0.1 \mathrm{~m}^{2}$. The tension of $60 \mathrm{kPa}$ corresponded to $0.15 \mathrm{~cm}^{3} \mathrm{~cm}^{-3}$ of water content in the soil, while the field capacity was $0.38 \mathrm{~cm}^{3} \mathrm{~cm}^{-3}$.

Monthly precipitations (mm) from January 20, 2016, to January 31,2017 , at the experiment site were concentrated from February to May (rainy season).
Climate variables were measured by a Campell ${ }^{\circledR}$ HOBO U30 automated weather station and consisted of precipitation $(\mathrm{mm})$, maximum and minimum temperatures $\left({ }^{\circ} \mathrm{C}\right)$, relative air humidity $(\%)$, solar radiation $\left(\mathrm{MJ} \mathrm{m} \mathrm{m}^{-2}\right.$ day $\left.^{-1}\right)$, wind speed $\left(\mathrm{km} \mathrm{day}^{-1}\right)$. The total rainfall during the seedling development was $1,085.5 \mathrm{~mm}$, while the reference evapotranspiration, estimated with the climate variables measured by the automated weather station using the Penman-Monteith method, was $1,451 \mathrm{~mm}$, with the need for water supply in the orchard.

In addition to seedling survival, the biometric variables evaluated consisted of the number of leaves per 
plant (NLPP), plant height (PH), stem diameter (SD), and canopy diameter (CD). Five plants were evaluated per plot. The variables NLPP and PH were evaluated monthly during the first six months and every two months for the remaining period. Moreover, the variables $\mathrm{SD}$ and $\mathrm{CD}$ were evaluated at the end of the experiment, i.e., at 374 days after transplantation (DAT).

Analyses of variance were performed using the GLM procedure of the statistical software SAS/STAT ${ }^{\circledR}$ version 9.3 to evaluate the effect of treatments on the response variables. The water demand for each treatment was monitored by the number of irrigations, considering the water from the accumulated precipitation, which was the same for all treatments $(1,085.5 \mathrm{~mm})$. The free software $\mathrm{R}$ version 3.6.3 was used to adjust regression models to evaluate the effects of doses of the applied soil amendments (biochar or hydrophilic polymer) on the volume of water used for irrigation.

\section{RESULTS AND DISCUSSION}

The means of the biometric characteristics of seedlings from 60 to 374 days after transplanting (DAT) to the field for different treatments are shown in Tables 2 and 3. A significant difference was observed only for the number of leaves per plant at 90 and 120 DAT (Table 2). No statistical difference was found after this period (F-test, $\mathrm{p}>0.05)$. The number of leaves varied from 9 to 13 at 60 $\mathrm{DAT}(\mathrm{CV}=16.6 \%)$ and from 187 to 304 at $374 \mathrm{DAT}$ $(\mathrm{CV}=27.8)$.

TABLE 2. Means of the number of leaves of seedlings from 60 to 374 days after transplanting under different treatments.

\begin{tabular}{|c|c|c|c|c|c|c|c|c|c|c|}
\hline \multirow{2}{*}{ DAT / Number of leaves } & \multicolumn{4}{|c|}{ Biochar $\left(\mathrm{kg} \mathrm{pit}^{-1}\right)$} & \multicolumn{4}{|c|}{ Hydrophilic polymer $\left(\mathrm{g} \mathrm{pit}^{-1}\right)$} & \multicolumn{2}{|l|}{ Control } \\
\hline & 0.5 & 1.0 & 2.0 & 4.0 & 20 & 40 & 60 & 80 & - & $\mathrm{CV}(\%)$ \\
\hline $60^{\mathrm{ns}}$ & 11 & 12 & 10 & 9 & 13 & 11 & 13 & 12 & 11 & 16.6 \\
\hline $90^{*}$ & $21^{\mathrm{a}}$ & $20^{\mathrm{a}, \mathrm{b}}$ & $15^{\mathrm{b}}$ & $13^{\mathrm{b}}$ & $21^{\mathrm{a}}$ & $19^{\mathrm{a}, \mathrm{b}}$ & $22^{\mathrm{a}}$ & $18^{\mathrm{a}, \mathrm{b}}$ & $20^{\mathrm{a}, \mathrm{b}}$ & 19.2 \\
\hline $120^{*}$ & $25^{\mathrm{b}}$ & $23^{b}$ & $24^{\mathrm{b}}$ & $23^{\mathrm{b}}$ & $32^{\mathrm{a}}$ & $26^{\mathrm{b}}$ & $34^{\mathrm{a}}$ & $27^{\mathrm{ab}}$ & $27^{\mathrm{ab}}$ & 16.8 \\
\hline $150^{\mathrm{ns}}$ & 45 & 51 & 44 & 42 & 55 & 47 & 62 & 46 & 49 & 10.2 \\
\hline $180^{\mathrm{ns}}$ & 66 & 72 & 58 & 60 & 77 & 58 & 83 & 70 & 61 & 10.8 \\
\hline $240^{\mathrm{ns}}$ & 88 & 82 & 76 & 91 & 105 & 79 & 122 & 93 & 103 & 13.0 \\
\hline $270^{\mathrm{ns}}$ & 96 & 108 & 99 & 106 & 120 & 99 & 160 & 122 & 128 & 13.9 \\
\hline $330^{\mathrm{ns}}$ & 139 & 132 & 118 & 124 & 164 & 120 & 204 & 153 & 163 & 18,9 \\
\hline $374^{\mathrm{ns}}$ & 216 & 187 & 237 & 230 & 265 & 230 & 304 & 301 & 259 & 27.8 \\
\hline
\end{tabular}

${ }^{\mathrm{ns}}$ No significance for statistical analysis using the SAS System ${ }^{\circledR}$.

Plant height varied according to the treatments from 23.9 to $25.8 \mathrm{~cm}(\mathrm{CV}=6.9 \%)$ and 70.5 to $76.6 \mathrm{~cm}(\mathrm{CV}=11.5 \%)$ from 60 to 374 DAT (Table 3), respectively.

TABLE 3. Means of seedling height $(\mathrm{cm})$ from 60 to 374 days after transplanting under different treatments.

\begin{tabular}{|c|c|c|c|c|c|c|c|c|c|c|}
\hline \multirow{2}{*}{ DAT $/$ Height $(\mathrm{cm})^{\mathrm{ns}}$} & \multicolumn{4}{|c|}{ Biochar $\left(\mathrm{kg} \mathrm{pit}^{-1}\right)$} & \multicolumn{4}{|c|}{ Hydrophilic polymer $\left(\mathrm{g} \mathrm{pit}^{-1}\right)$} & \multirow[t]{2}{*}{ Control } & \multirow[b]{2}{*}{$\mathrm{CV}(\%)$} \\
\hline & 0.5 & 1.0 & 2.0 & 4.0 & 20 & 40 & 60 & 80 & & \\
\hline $60^{\mathrm{ns}}$ & 24.0 & 25.4 & 23.9 & 23.9 & 24.6 & 25.6 & 24.0 & 25.8 & 24.3 & 6.9 \\
\hline $90^{\mathrm{ns}}$ & 28.3 & 32.4 & 29.2 & 28.7 & 31.8 & 32.8 & 32.1 & 32.7 & 31.4 & 12.9 \\
\hline $120^{\mathrm{ns}}$ & 35.2 & 37.8 & 34.3 & 33.7 & 36.6 & 35.9 & 39.3 & 35.3 & 37.1 & 9.7 \\
\hline $150^{\mathrm{ns}}$ & 46.8 & 50.0 & 45.6 & 44.8 & 48.7 & 47.9 & 50.6 & 45.2 & 49.4 & 5.1 \\
\hline $180^{\mathrm{ns}}$ & 54.9 & 58.0 & 56.7 & 57.6 & 59.4 & 58.3 & 62.6 & 54.7 & 57.2 & 6.1 \\
\hline $240^{\mathrm{ns}}$ & 65.3 & 63.9 & 63.4 & 66.5 & 65.8 & 63.7 & 67.9 & 59.6 & 66.3 & 4.9 \\
\hline $270^{\mathrm{ns}}$ & 63.7 & 61.8 & 62.9 & 66.6 & 66.1 & 66.6 & 75.0 & 61.4 & 70.1 & 5.9 \\
\hline $330^{\mathrm{ns}}$ & 69.5 & 68.2 & 67.8 & 66.0 & 71.6 & 68.3 & 75.1 & 62.2 & 72.0 & 4.8 \\
\hline $374^{\mathrm{ns}}$ & 70.9 & 71.7 & 73.2 & 71.2 & 71.4 & 70.5 & 74.9 & 76.6 & 70.9 & 11.5 \\
\hline
\end{tabular}

${ }^{n s}$ No significance for statistical analysis using the SAS System ${ }^{\circledR}$.

Stem diameter and canopy varied from 38.0 to 45.7 $\mathrm{cm}(\mathrm{CV}=10.4 \%)$ and canopy 81.3 to $114.6 \mathrm{~cm}(\mathrm{CV}=$ $15.4 \%$ ), respectively at 374 DAT (Table 4 ). The survival rates (Table 4) obtained from the different treatments of this study ranged from 70.8 to $100.0 \%(\mathrm{CV}=10.3 \%)$, which is considered satisfactory compared to the results found by Serrano et al. (2015) in the semiarid region of
Piauí in an eight-year-old BRS 226 orchard under the rainfed regime. These authors observed survival rates from 75 to $86 \%$, with a mean of $79.63 \%(\mathrm{CV}=16.1 \%)$, depending on the used rootstock. In the present study, most of the observed values were higher, which can be attributed to the irrigations, as the time of exposure of plants to water stress was minimized (Table 5). 
TABLE 4. Means of biometric characteristics and survival of seedlings at 374 days after transplanting under different treatments.

\begin{tabular}{|c|c|c|c|c|c|c|c|c|c|c|}
\hline \multirow[t]{2}{*}{ Biometric characteristics } & \multicolumn{4}{|c|}{$\operatorname{Biochar}\left(\mathrm{kg} \mathrm{pit}{ }^{-1}\right)$} & \multicolumn{4}{|c|}{ Hydrophilic polymer $\left(\mathrm{g} \mathrm{pit}^{-1}\right)$} & \multicolumn{2}{|l|}{ Control } \\
\hline & 0.5 & 1.0 & 2.0 & 4.0 & 20 & 40 & 60 & 80 & - & $\mathrm{CV}(\%)$ \\
\hline Stem diameter $(\mathrm{mm})^{\mathrm{ns}}$ & 38.0 & 39.4 & 40.1 & 41.6 & 42.2 & 40.7 & 45.1 & 45.7 & 41.1 & 10.4 \\
\hline Canopy $(\mathrm{cm})^{\mathrm{ns}}$ & 86.6 & 81.3 & 85.9 & 94.1 & 93.4 & 89.9 & 114.6 & 103.4 & 91.1 & 15.4 \\
\hline Survival (\%) & 91.7 & 87.5 & 87.5 & 70.8 & 100.0 & 95.8 & 83.3 & 100.0 & 95.8 & 10.3 \\
\hline
\end{tabular}

${ }^{\mathrm{ns}}$ No significance for statistical analysis using the SAS System ${ }^{\circledR}$.

The adjustment of the regression model that describes the relationship between the dose of biochar $(\mathrm{kg})$ and the volume of water applied per plant (L) during the 12 months of irrigation was not significant $(\mathrm{p}>0.05)$. Therefore, the reduction in water consumption by the additive effect of inputs could not be consistently explained (Table 5). Thus, further experiments with a high number of treatments or replications can be planned, considering the costs associated with increased sampling. Vinh et al. (2015) applied rice husk biochar to six-year-old cashew trees and reported an increase in soil moisture only at the application depth $(0.20 \mathrm{~m})$. In this case, the desired effect may require a new application as seedlings deepen their root system.

TABLE 5. Number of irrigation operations and annual water volume applied per treatment.

\begin{tabular}{lccccccccc}
\hline & \multicolumn{4}{c}{ Biochar $\left(\mathrm{kg} \mathrm{pit}^{-1}\right)$} & \multicolumn{5}{c}{ Hydrophilic polymer $\left.(\mathrm{g} \mathrm{pit})^{-1}\right)$} \\
\hline Variable & 0.5 & 1.0 & 2.0 & 4.0 & 20 & 40 & 60 & 80 & - \\
\hline Water volume (L) & 70 & 70 & 90 & 150 & 55 & 55 & 125 & 150 & 120 \\
Irrigation number & 14 & 14 & 18 & 30 & 11 & 11 & 25 & 30 & 24 \\
Cost/ha (R\$1.00 in 18.09.01)* & 700.00 & 700.00 & 900.00 & $1,500.00$ & 550.00 & 550.00 & $1,250.00$ & $1,500.00$ & $1,200.00$ \\
\hline
\end{tabular}

$\left(^{*}\right)$ Based on the cost of R $\$ 100.00$ per hour, including tractor driver.

A quadratic regression model $\left(\mathrm{R}^{2}=0.99, \mathrm{p}=\right.$ 0.01054 , Figure 1) was adjusted between the amount of hydrophilic polymer (zero to $60 \mathrm{~g}$ ) and the water volume applied during the 12 months of irrigation. The minimum water consumption ( $46 \mathrm{~L} \mathrm{plant}^{-1}$ ) corresponded to the dose of $29.5 \mathrm{~g} \mathrm{pit}^{-1}$ of hydrophilic polymer per plant. The control treatment, without hydrophilic polymer, had water demand similar to the dose of $60 \mathrm{~g}$ of the hydrophilic polymer, but higher than the demands for doses of 20 and
$40 \mathrm{~g} \mathrm{pit}^{-1}$. Water demand increased together with higher polymer doses of $29.5 \mathrm{~g} \mathrm{pit}^{-1}$, possibly because the moisture is retained in the polymer and less available to plants at the root zone. The treatment corresponding to the dose $80 \mathrm{~g}$ was excluded from the adjusted model because part of the applied polymer was expelled to the soil surface during the experiment due to intense rainfall, suggesting an excessive amount. Therefore, the expelled amount started to not respond to its additive effect due to this occurrence.

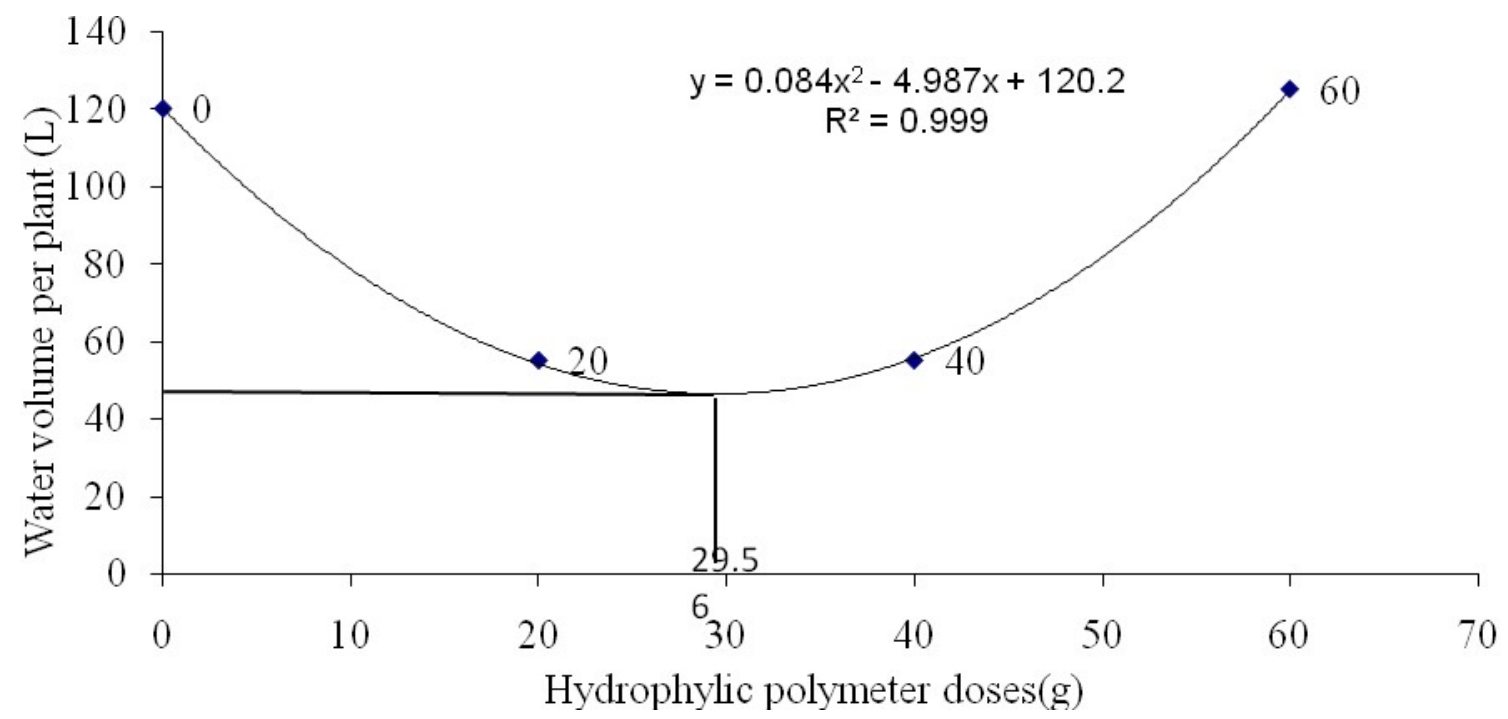

FIGURE 1. Adjusted quadratic model $(\mathrm{p}=0.01054)$ and $\mathrm{p}$ of the t-test of equation coefficients $\left(\mathrm{x}^{2}: 0.01054\right),(\mathrm{x}: 0.01116)$, and (intercept: 0.0057$)$ to describe the relationship between the dose of hydrophilic polymer (kg) and volume of water applied per plant (L) in 12 months of rescue irrigation in Paraipaba, CE, Brazil. 
Several studies have been developed with seedlings and plants on the application of high doses of hydrophilic polymers, but they have not found the expected positive effects. Nomura et al. (2019) worked with papaya seedlings grown in plastic bags and reported a positive effect on the biometry of plants when using 4 and $6 \mathrm{~g}$ of the hydrophilic polymer. Its increased concentration led to a decrease in the evaluated parameters, while a higher concentration interfered negatively with seedling growth. Tatagiba et al. (2019) reported that the polymer negatively affected the rooting of eucalyptus cuttings and survival of plants as the water depth applied on the substrate decreased, while the increasing hydrophilic polymer dose showed no increase in the substrate moisture. Kraisig et al. (2018) demonstrated an optimal level of concentration and decreased performance due to an increase in the polymer dose, explained by regression and surface response. Dranski et al. (2013) reported that doses above the recommended had a reduction effect on seedling growth under the conditions of western Paraná. Gervásio \& Frizzone (2004) reported that excellent results obtained under laboratory conditions, mainly in terms of absorption and reabsorption, are not the same when using the soil amendment mixed with the substrate. The activity of hydro-absorbent polymers is reduced for water retention when added to an organic substrate, which may be due to the lack of free water in the substrate, limiting its expansion.

The number of irrigation operations per treatment was lower in treatments with 20 and $40 \mathrm{~g}$ of polymer, demonstrating that treatments with lower demand of water volume $(55 \mathrm{~L})$ had fewer irrigation operations, i.e., 11 irrigations (Table 5). The lowest annual operations cost of using rescue irrigation represents approximately $46 \%$ of the total spent on the control treatment. This cost reaches $\mathrm{R} \$ 1,716.00$ annually because it is currently recommended to apply $25 \mathrm{~L}$ water week ${ }^{-1}$ to each seedling, being higher than all the studied treatments. In this case, the annual consumption represents $800 \mathrm{~L}$ water seedling ${ }^{-1}$ in eight months of irrigation in the case where precipitations around the mean occur during the rainy season (February to May).

Variations in the soil moisture content of all treatments at the $0-0.30 \mathrm{~m}$ soil layer are shown in Figure

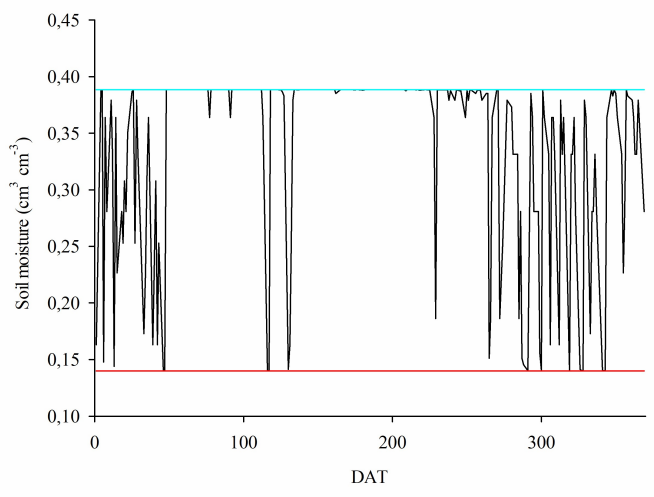

A. $0.5 \mathrm{~kg}$ biochar per pit
2 , resulting from readings of tensiometers installed at a depth of $0.15 \mathrm{~m}$. The critical moisture of $60 \mathrm{kPa}$ was adopted to start rescue irrigation of $5 \mathrm{~L} \mathrm{plant}^{-1}$ in the nine applied treatments over the 374 days after transplanting (DAT). Soil moisture values on the $\mathrm{Y}$-axis varied from $0.15(60 \mathrm{kPa})$ to $0.38 \mathrm{~cm}^{3} \mathrm{~cm}^{-3}$ at the field capacity, equaling the minimum soil moisture content that occurred in each treatment. Treatments with the highest frequency in which soil water content reaches $0.15 \mathrm{~cm}^{3} \mathrm{~cm}^{-3}$ are related to higher water demand and, therefore, more frequent irrigation operations.

Although soil moisture tension did not exceed 60 $\mathrm{kPa}$ on most days, as planned, soil moisture varied between the different treatments, notably in treatments with $4 \mathrm{~kg}$ of biochar and $80 \mathrm{~g}$ of polymer (Figure 2), which corresponded to the treatments with the highest doses of biochar and polymer, respectively. In this sense, these treatments had their moisture close to $60 \mathrm{kPa}$ more frequently, corroborating with the thesis that soil amendments at high amounts retain water and become it less easily available to plants, thus requiring a higher frequency of rescue irrigation (Table 5).

Treatments with $0.5 \mathrm{~kg}$ of biochar and $20 \mathrm{~g}$ of polymer demanded the least number of irrigation operations (Table 5), with the lowest levels of biochar and hydrophilic polymer applied, respectively, being able to maintain moisture available to plants for a longer time. The treatment with $40 \mathrm{~g}$ of polymer provided higher available soil moisture with the same amount of water than the treatment with $20 \mathrm{~g}$ of polymer, but with higher amounts of soil amendments. Treatments with 2.0 and 4.0 $\mathrm{kg}$ of biochar, 60 and $80 \mathrm{~g}$ of hydrophilic polymer, and the control demanded a higher irrigation frequency to maintain the moisture tension below $60 \mathrm{kPa}$ relative to the treatments of 0.5 and $1.0 \mathrm{~kg}$ of biochar and 20 and $40 \mathrm{~g}$ of polymer (Table 5 and Figure 2).

Both biochar and polymer remained active in terms of their water retention capacity throughout the monitoring period (Figure 2), which can be very useful in a semiarid region that has a dry period from seven to eight months. The obtained results showed that doses of 20 and $40 \mathrm{~g}$ of hydrophilic polymer favor the soil moisture conservation, which may minimize the mortality of cashew plants in the first year after planting in the field.

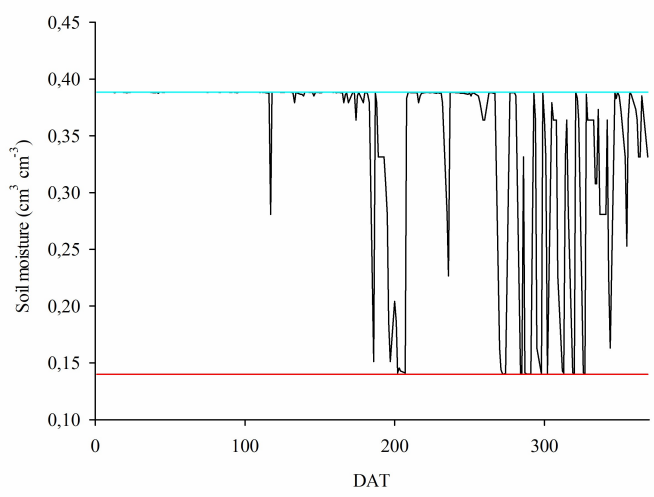

B. $1.0 \mathrm{~kg}$ biochar per pit 


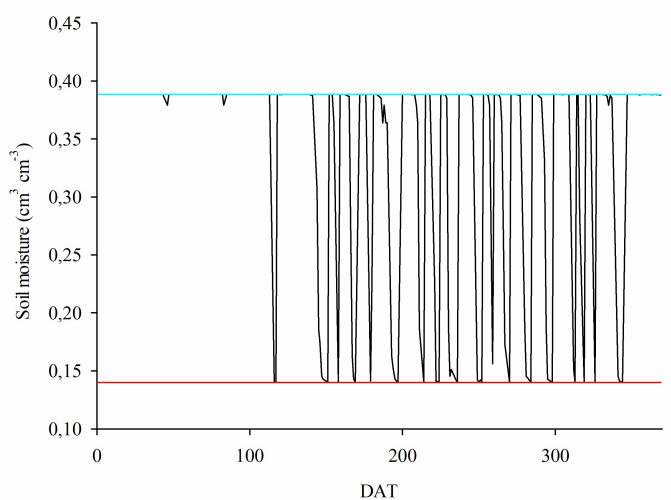

C. $2.0 \mathrm{~kg}$ biochar per pit

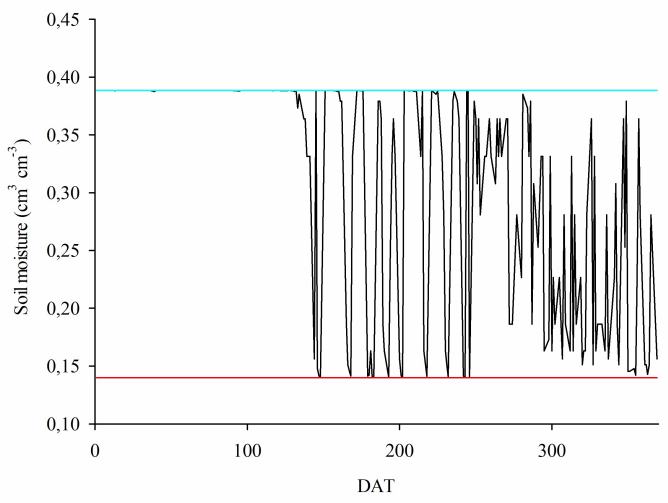

E. $20 \mathrm{~g}$ hydrophilic polymer per pit

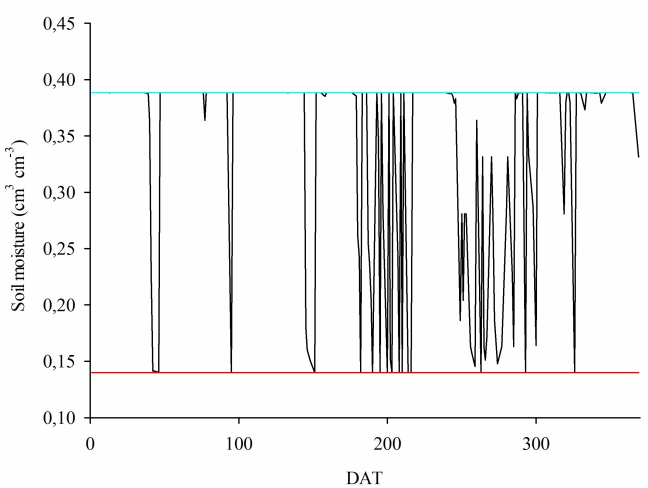

G. 60 g hydrophilic polymer per pit

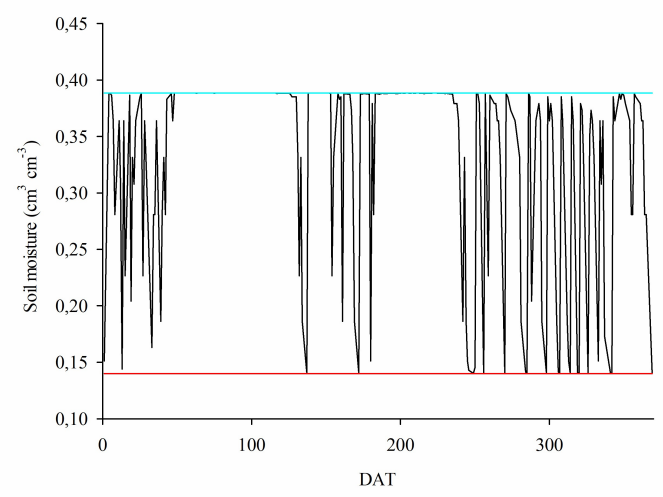

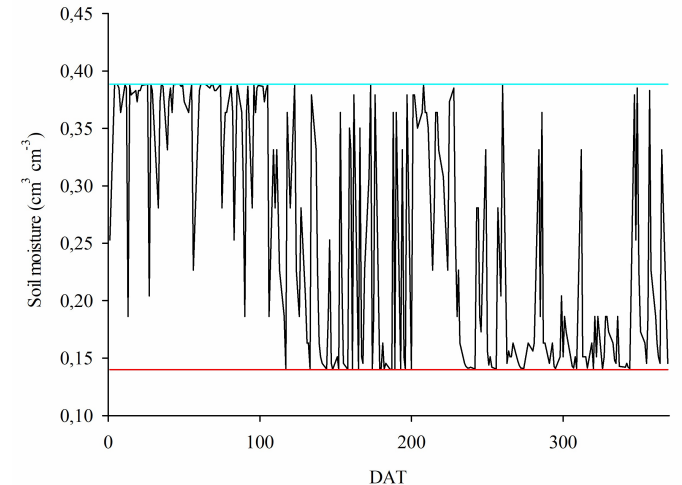

D. $4.0 \mathrm{~kg}$ biochar per pit

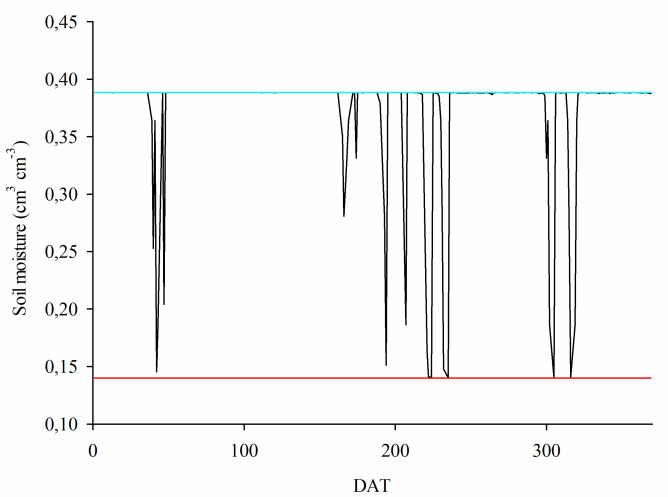

F. $40 \mathrm{~g}$ hydrophilic polymer per pit

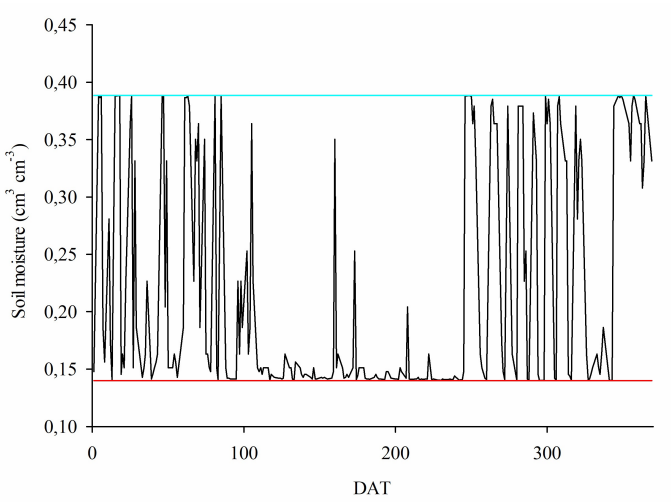

H. 80 g hydrophilic polymer per pit

Soil moisture Field capacity Irrigation

\section{Control}

FIGURE 2. Effect over time of different doses of biochar and hydrophilic polymer on the variation of soil moisture content $\left(\mathrm{cm}^{3} \mathrm{~cm}^{-3}\right)$ at a depth of $0.15 \mathrm{~m}$ for different treatments. A. 0.5, B. 1.0, C. 2.0, and D. $4.0 \mathrm{~kg}$ of biochar pit ${ }^{-1}$; E. 20, F. 40, G. 60 , and H. 80 g of hydrophilic polymer pit ${ }^{-1}$; and I. Control up to 374 DAT in Paraipaba, CE, Brazil. 


\section{CONCLUSIONS}

Biochar and hydrophilic polymer application showed no influence on the cashew seedling development during the first year after planting in the field.

The dose of $29.56 \mathrm{~g} \mathrm{pit}^{-1}$ of polymer is indicated for maximizing water retention, representing a lower number of irrigation operations in the field and reducing the associated costs and higher level of plant survival.

There is a need for further research regarding the cashew wood biochar to enable consistent and substantiated indications.

\section{ACKNOWLEDGMENTS}

To the Brazilian Agricultural Research Corporation (Embrapa) and the National Council for Scientific and Technological Development (CNPq).

\section{REFERENCES}

Alencar PG de, Espindola GM de, Carneiro ELN da C (2018) Dwarf cashew crop expansion in the Brazilian semiarid region: Assessing policy alternatives in Pio IX, Piauí. Land Use Policy 79:1-9. DOI:

https://doi.org/10.1016/j.landusepol.2018.07.042

Batista EMCC, Shultz J, Matos TTS, Fornari MR, Ferreira TM, Szpoganicz B, Freitas RA de, Mangrich AS (2018) Effect of surface and porosity of biochar on water holding capacity aiming indirectly at preservation of the Amazon biome. Scientific Reports 8:10677. DOI: https://doi.org/10.1038/s41598-018-28794-z

Carr MKV (2014) The water relations and irrigation requirements of cashew (Anacardium occidentale L.): a review. Experimental Agriculture 50(1):24-39. DOI: https://doi.org/10.1017/S0014479713000288

Danso EO, Yakubu A, Darrah YKO, Arthur E, Manevski K, Sabi EB, Abenney-Mikison S, Ofori K, Plauborg F, Andersen MN (2019) Impact of rice straw biochar and irrigation on maize yield, intercepted radiation and water productivity in a tropical sandy clay loam. Field Crops Research 243:1-11. DOI:

https://doi.org/10.1016/j.fcr.2019.107628

Dranski JAL, Junior ASP, Campagnolo MA, Malavasi UC, Malavasi MM (2013) Sobrevivência e crescimento do pinhão-manso em função do método de aplicação e formulações de hidrogel. Revista Brasileira de Engenharia Agrícola e Ambiental 17(5):537-542.

Elshaikh NA, Zhipeng L, Dongli S, Timm LC (2017) Increasing the okra salt threshold value with biochar amendments. Journal of Plant Interactions 13(1):51-63. DOI: https://doi.org/10.1080/17429145.2017.1418914

Embrapa (2013) Centro Nacional de Pesquisa de Solos. Sistema brasileiro de classificação de solos. Brasília: Embrapa Informação Tecnológica, 3 ed. 353 p.

Gervásio ES, Frizzone JA (2004) Caracterização físicohídrica de um condicionador de solo e seus efeitos quando misturado a um substrato orgânico. Irriga 9(2):94-105.
Gondim RS, Muniz CR, Lima CEP, dos Santos CLA (2018) Explaining the water-holding capacity of biochar by scanning electron microscope images. Revista Caatinga 31(4):972-979. DOI: https://doi.org/10.1590/198321252018v31n420rc

Gonzaga MIS, da Silva, PSO, Santos JSJ, de Oliveira Jr. LFG (2019) Biochar increases plant water use efficiency and biomass production while reducing $\mathrm{Cu}$ concentration in Brassica juncea L. in a $\mathrm{Cu}$-contaminated soil. Exocoticology and Environmental Safety 183:1-6. DOI: https://doi.org/10.1016/j.ecoenv.2019.109557

Güereña DT, Lehman J, Thies JE, Vaneck J, Karanja N, Neufeldt H (2019) Nodulation of beans with inoculant carriers from pyrolyzed and non-pyrolyzed sugarcane bagasse in response to different pre-planting water availability. Applied Soil Ecology 143:126-133. DOI: https://doi.org/10.1016/j.apsoil.2019.06.010

Kammann CI, Linsel S, Göbling JW, Koyro HW (2011) Influence of biochar on drought tolerance of Chenopodium quinoa Willd and on soil-plant relations. Plant Soil 345(1):195-210. DOI: https://doi.org/10.1007/s11104-0110771-5

Karhu K, Tuomas M, Irina B, Kristiina R (2011) Biochar addition to agricultural soil increased $\mathrm{CH}_{4}$ uptake and water holding capacity - Results from a short-term pilot field study. Agriculture, Ecosystems \& Environment 140(1-2):309-313. DOI:

https://doi.org/doi:10.1016/j.agee.2010.12.005

Kraisig AR, Scremin OB, Mantai RD, Marolli A, Mamann ATW, Brezolin AP, Alessi O, da Silva JAG (2018)

Regressão por Superfície de Resposta pelo Uso Combinado de Nitrogênio e Hidrogel no Sistema Milho/Aveia. Proceeding Series of the Brazilian Society of Computational and Applied mathematics 6(2):1-7. DOI: https://doi.org/10.5540/03.2018.006.02.0437

Lim TJ, Spokas KA, Feyereisen G, Novak JM (2016) Predicting the impact of biochar additions on soil hydraulic properties. Cremosphere 142:136-144. DOI: http://dx.doi.org/10.1016/j.chemosphere.2015.06.069

Mangalassery S, Rejani R, Singh V, Adiga JD, Kalaivanan D, Rupa TR, Philip OS (2019) Impact of different irrigation regimes under varied planting density on growth, yield and economic return of cashew (Anacardium occidentale L.). Irrigation Science 37(4):483-494. DOI: https://doi.org/10.1007/s00271-019-00625-7

Mao J, Zhang K, Chen B (2019) Linking hydrophobicity of biochar to the water repellency and water holding capacity of biochar-amended soil. Environmental Pollution 253:779-789. DOI: https://doi.org/10.1016/j.envpol.2019.07.051

Marques PAA, Cripa MA de M, Martinez EH (2013) Hidrogel como substituto da irrigação complementar em viveiro telado de mudas de cafeeiro. Ciência Rural 43(1):1-7. DOI: http://dx.doi.org/10.1590/S010384782012005000129 
Moragues-Saitua L, Arias-González A, Gartzia-

Bengoetxea N (2017) Effects of biochar and wood ash on soil hydraulic properties: A field experiment involving contrasting temperate soils. Geoderma 305:144-152. DOI: http://dx.doi.org/10.1016/j.geoderma.2017.05.041

Muniz FL, Pereira JMR, Júnior CLX, Studar MdeC (2017) Classificação climática para o estado do ceará utilizando distintos sistemas de caracterização. In: Simpósio Brasileiro de Recursos Hídricos. Florianópolis, Associação Brasileira de Recursos Hídricos, Anais...

Nomura M, Filho JMP, Costa EM, Pereira LS, Ventura, MVA (2019) Avaliação de diferentes quantidades de hidrogel na produção de mudas de mamão papaya. Agronomic Journal 3(1):19-25.

Novotny EH, Maia CMB de F, Carvalho MT de M, Madari BE (2015) Biochar: pyrogenic carbon for agricultural use - a critical review. Revista Brasileira de Ciência do Solo 39(2):321-344. DOI:

http://dx.doi.org/10.1590/01000683rbcs20140818

Omondi MO, Xia X, Nahay OA, Liu X, Korai PK, Pan G (2016) Quantification of biochar effects on soil hydrological properties using meta-analysis of literature data. Geoderma 274(1):28-34. DOI:

http://dx.doi.org/10.1016/j.geoderma.2016.03.029

Pimenta AS, Miranda NO, de Carvalho MAB, da Silva, GGC, Oliveira EMM (2019) Effects of biochar addition on chemical properties of a sandy soil from northeast Brazil. Arabian Journal of Geosciences 12(70):1-6. DOI: https://doi.org/10.1007/s12517-018-4194-y

Rejani R, Yadukumar N (2010) Soil and water conservation techniques in cashew grown along steep hill slopes. Scientia Horticulturae 126(3):371-378. DOI: https://doi.org/10.1016/j.scienta.2010.07.032

Sajeev MV, Saroj PL, Lakshmisha R (2014) Technology impacts on area, production and productivity of cashew in Dakshina Kannada district, Karnataka. Journal of Plantation Crops 42(1):62-69.
Sarvas M, Pavlenda P, Takácová E (2007) Effect of hydrogel application on survival and growth of pine seedlings in reclamations. Journal of Forest Science 53(5):204-209.

Serrano LAL, Vidal Neto F das C, Melo DS, Cavalcanti JJV, Rosseti AG (2015) Porta-enxertos para os cajueirosanões 'CCP 76' e 'BRS 226' no semiárido do Piauí. Fortaleza, Embrapa Agroindústria Tropical, 24 p. Boletim de Pesquisa e Desenvolvimento, 107.

Tatagiba SD, Silva AG da, Filho RMP, Reis EF dos, Ramos KA (2019) Disponibilidade hídrica e doses de polímero hidrorretentor na produção de mudas clonais de eucalipto. Revista Engenharia na Agricultura 27(4):359-369.

Vinh H, Tam HM, Bell RW, Mann S, Nhan DT, Thuong NT, Cuong HH, Bao PV, Keen B, Slavich P (2015) Integrated nutrient management of annual and perennial crops on sandy coastal plains of south-central coastal Vietnam In: Mann S, Webb MC, Bell RW (eds). Sustainable and profitable crop and livestock systems in south-central coastal Vietnam. Canberra: Australian Centre for International Agricultural Research, 240 p.

Verheijen FGA, Zhuravel A, Silva FC, Amaro A, Ben-Hur M, Keizer, JJ (2019) The influence of biochar particle size and concentration on bulk density and maximum water holding capacity of sandy vs sandy loam soil in a column experimente, Geoderma 347:194-202. DOI: https://doi.org/10.1016/j.geoderma.2019.03.044

Villagra-Mendoza K, Horn R (2018) Effect of biochar addition on hydraulic functions of two textural soil. Geoderma 326:88-95. DOI: https://doi.org/10.1016/j.geoderma.2018.03.021

Xavier FAS, Maia SMF, Ribeiro KA, Mendonça ES, Oliveira TS (2013) Effect of cover plants on soil C and N dynamics in different soil management systems in dwarf cashew culture. Agriculture, Ecosystems and Environment 165(1):173-183. DOI: http://dx.doi.org/10.1016/j.agee.2012.12.003 